\title{
Balancing urban green space and residential infill development: A spatial multi-criteria approach based on practitioner engagement
}

The objectives in consolidating the urban form and preserving green spaces are often in conflict in growing cities. The usability of spatial multi-criteria decision analysis (SMCDA) was tested as a tool for integrating residential infill development and urban green spaces in the City of Järvenpää, Finland. In collaboration with local practitioners, this study focused on the benefits and challenges of SMCDA. The results were based on two workshops with the practitioners along with comprehensive GIS analyses based on a wide range of available data. The practitioners saw SMCDA as a useful method to bring together a variety of factors related to infill development. They highlighted the importance of the method's transparency, emphasising the comprehensive explanation of each step of the method. Better understanding of the impact of individual criteria weightings on the results was mentioned as one of the key future developments of the method.

Keywords: Land-use planning, spatial multi-criteria decision analysis, infill development, green infrastructure, ecosystem services

\section{Introduction}

Urbanisation dynamics in western cities have been increasingly shifting from low-density urban sprawl to more compact cities (Delmelle et al., 2014; Sarzynski et al., 2014). Background drivers for this shift include not only demographic changes like population aging, economic situation and change in people's housing preferences (Delmelle et al., 2014), but also the objective of reducing traffic-related greenhouse gas emissions by urban planning (Pharoah, 1996; Kenworthy, 2007; Kimball et al., 2013). However, the densification of cities has raised a question of shrinkage in urban green areas (Fuller and Gaston, 2009; Brunner and Cozens, 2013; Kabisch and Haase, 2013; Haaland and van den Bosch, 2015). That is considered a significant issue, since natural and semi-natural areas maintain and support vital ecosystem 
services, including many which support the well-being of people and climate change adaptation in cities (Millenium Ecosystem Assessment, 2005).

The need for tools to recognise trade-offs (especially concerning urban densification), in order to protect the benefits of urban green spaces, has been acknowledged (Dallimer et al., 2011). Furthermore, the increasing amount of available data requires tractable methods to aggregate information into a useful form for planners (Kiker et al., 2005). That may explain the growing use of decision support systems, such as spatial multi-criteria decision analysis (SMCDA) (Malczewski, 2006).

In 1990-2004, the most common application domains of SMCDA were environmental/ecological, transportation and urban/regional planning (Malczewski, 2006). SMCDA has been applied in a variety of planning problems - on the one hand for finding optimal locations for controversial land uses like landfill (Geneletti, 2010; Angilella et al., 2016), transport infrastructure (Geneletti, 2005; Ferretti, 2016) and powerlines (Bagli et al., 2011), and on the other hand for biodiversity conservation and ecosystem services (Geneletti and van Duren, 2008; Ianni and Geneletti, 2010; Orsi and Geneletti, 2010; Bottero et al., 2013; Ferretti and Pomarico, 2013, Karjalainen et al., 2013; Kremer et al., 2016). The spatial dimension added to MCDA is particularly useful in land-use planning, since it can take into account the differences in the spatial characteristic of the region, while combining factual data with value-based information needed in decision-making (Mahmoud and Garcia, 2000; Janssen et al., 2005). A critical step of (S)MCDA is criteria weighting, due to its inherent subjective nature. Already in the 1990s, Banville et al. (1998) argued that MCDA need to consider the socio-political aspects more and the decision-makers' role often merely consists of 'answering questions from experts who need their answers to operate their model'. The number of studies applying SMCDA has grown rapidly since the 1990s (Malczewski, 2006). Yet even today, interaction and the underlying processes behind stakeholder weightings are still often insufficiently documented, and only a few studies explicitly deal with the role and feedback of the stakeholders in the process (Marttunen et al., 2015; Ferretti, 2016). 
In this study, the application of SMCDA was tested for integrating urban green spaces and residential infill development in the rather compact, growing City of Järvenpää in southern Finland. Our main research question was: What are the benefits and challenges in applying SMCDA to the integration of urban green spaces and infill development? To answer this question, we provide a detailed description of the process, focusing on: i) continuous collaboration with local practitioners, ii) possible conflicts and challenges during the process, and iii) finding common priorities and getting feedback on how the method could be enhanced for wider use in land-use planning.

\section{Methods}

We applied a GIS-based Multi-Attribute Value Theory (MAVT) approach, which is a widely used technique for supporting decision-making, especially in the environmental field and in urban planning (Huang et al., 2011; Ferretti and Comino, 2015). It can be used to structure and harmonise complex planning problems by organising planning goals and evaluating the criteria against these goals. Evaluation is typically based to the value function associated with each criteria using e.g. weighted sum approach where all of the single criteria are separately weighted and combined using scaling constants (Delle Site and Filippi, 2009).

With the possibility to handle both quantitative and qualitative data, MAVT provides a tool to compare and evaluate the social, ecological and economic impacts related to land use planning by aggregating the perspectives across all the criteria to form an overall assessment. Concerning the 'black box effect', one of the main goals of MAVT is to find a simple tool to capture decision-maker preferences in a transparent way (Kiker et al., 2005).

Preparatory discussions with the practitioners of the case city strengthened the vision that the planners required a method that is based on valid research, is simple to use, and produces understandable results that can easily be implemented in land use planning. Integrating MAVT with GIS, we could: i) evaluate 3 
the decisions spatially ii) produce alternative land suitability scenarios in which different decisions could be directly compared on a map iii) utilise both GIS software and expert knowledge iv) avoid the black box effect, by having simplified elicitation protocols and ensuring the transparency of the model by explaining all the relevant analyses and phases in a simple manner.

Our proposed approach is presented in Figure 1 and described in detail in the following sub-sections. Many of the phases include collaboration between researchers and stakeholders. To highlight the differences between different stages of the process, we also provide an explicit step-by-step representation of the roles of different actors during the process. 
R I. Definition of the planning problem: optimal integration of the green infrastructure $(\mathrm{Gl})$ and infill development to support the socially, ecologically and economically sustainable urban planning

2. SMCDA review and design - preliminary draft of the objectives and related criteria as a decision tree

\section{WEIGHTING WORKSHOP}

$\mathrm{R}$

I. Presentation on the SMCDA method and the draft of the value tree

P 2. Joint discussion and adjustment of the objectives and the criteria

3. Weighting the criteria

\section{DATA ANALYSIS}

I. Selecting spatial data to represent the criteria

2. Scoring the data according to the workshop weightings

$R \quad$ 3. Producing output maps of the potential infill development sites based on the workshop weightings

4. Sending maps to the practitioners

\section{FEEDBACKWORKSHOP}

$\mathrm{R} \quad \mathrm{I}$. Presentation on the data analysis and results

2. Round-table discussion on the results according to predefined questions

Fig. 1. General workflow of the process. R describes a phase where the contribution of researchers was involved. P describes a phase where the contribution of the practitioners was involved. Green infrastructure (GI) is defined as interconnected green space network that is planned and managed for the provision of different ecosystem services (Benedict and McMahon, 2012). 


\subsection{Study design}

In our process, the main objective was to support the integration of green infrastructure (GI) and infill development in the City of Järvenpää. Järvenpää is a compact Finnish city having an expected population growth of over $10 \%$ by the year 2030 (Official Statistics of Finland 2018). Since this growing city is small in area, there is an exceptionally strong need for infill development to provide housing for new inhabitants. However, the city planners were keen on not causing deteriorating impacts on natural values and ecosystem services provided by green and blue areas. One planning target was to preserve and even enhance the green infrastructure inside the city while simultaneously identifying land for future developments.

According to Keeney and Gregory (2005), certain characteristics related to the selection of the appropriate criteria should be taken into account when constructing the value tree (Table 1). Following this listing and previous knowledge of the spatial assessment of the potential provision of ecosystem services and connectivity of urban green in the City of Järvenpää (Kopperoinen et al., 2016), we drafted the initial version of the value tree, including the objectives and criteria. The drafted version of the value tree was sent to the practitioners before the first workshop. 
(2005).

\begin{tabular}{|c|l|}
\hline Unambiguous & $\begin{array}{l}\text { A clear relationship exists between consequences } \\
\text { and descriptions of consequences using the criteria. }\end{array}$ \\
\hline Comprehensive & $\begin{array}{l}\text { The criteria cover the range of possible } \\
\text { consequences for the corresponding objective, and } \\
\text { value jud gments implicit in the criteria are } \\
\text { reasonable. }\end{array}$ \\
\hline Direct & $\begin{array}{l}\text { The criteria directly describe the consequences of } \\
\text { interest. }\end{array}$ \\
\hline Operational & $\begin{array}{l}\text { In practice, information to describe consequences } \\
\text { can be obtained and value trade-offs can reasonably } \\
\text { be made. }\end{array}$ \\
\hline Understandable & $\begin{array}{l}\text { Consequences and value trade-offs made using the } \\
\text { criteria can readily be understood and clearly } \\
\text { communicated. }\end{array}$ \\
\hline
\end{tabular}


The drafted value tree was further developed in co-operation with the practitioners during the weighting workshop (Fig. 2.). The value tree was constituted of criteria within different hierarchy levels. The upperlevel criteria were more general and were specified using sub-criteria. The value tree was divided into two different themes:

i. Green infrastructure, where the objective was to identify and preserve the most valuable nature areas.

ii. Infill development, where the objective was to identify the most optimal areas for construction.

Green infrastructure was evaluated using the three sub-criteria of biodiversity, structural connectivity of urban green spaces, and potential provision of ecosystem services. Optimal infill development sites were evaluated by utilising the existing infrastructure in terms of saving construction costs, promoting sustainable travel behaviour, minimizing distances to the most crucial daily services, and minimizing exposure to nuisances and disturbance.

\subsection{Weighting workshop}

Two separate workshops were organised during the whole process. The first workshop focused on identifying and structuring objectives and criteria and weighting them. The researchers in cooperation with one of the city planners invited a total of nine experts to the workshops from different sectors of the city, including: master planning (3 people), town planning (1), health and welfare (1), children and youth services (1), maintenance of green areas (1), forestry (1), and the environment sector (1). In the workshop, both the objectives and criteria described in the drafted value tree were further discussed and altered onthe-fly according to the joint discussion based on the participants' expert knowledge in various sectors.

Swing technique is a typical method used for weighting the criteria in MAVT. It is based on the evaluator considerations of the importance of difference in the impacts between the best and worst alternative across the criteria (Delle Site and Filippi, 2009). However, this could create unwanted confrontations 
especially in sensitive themes of GI and infill development that are both important urban dimensions and should be equally addressed in planning. We used a modified version of the swing technique were the practitioners weighted the GI and infill development criteria separately based on the importance of the criteria's impact on the objectives. Weights of the criteria were given individually using scoring from zero to hundred in order to avoid the 'group think' effect, which is considered one of the controversial tendencies of group-based decision-making (Kiker et al., 2005). By the end of the workshop, the value tree included a common view on the objectives and relevant criteria to support the integration of GI and infill development (Fig. 2) along with the practitioners' weightings. 


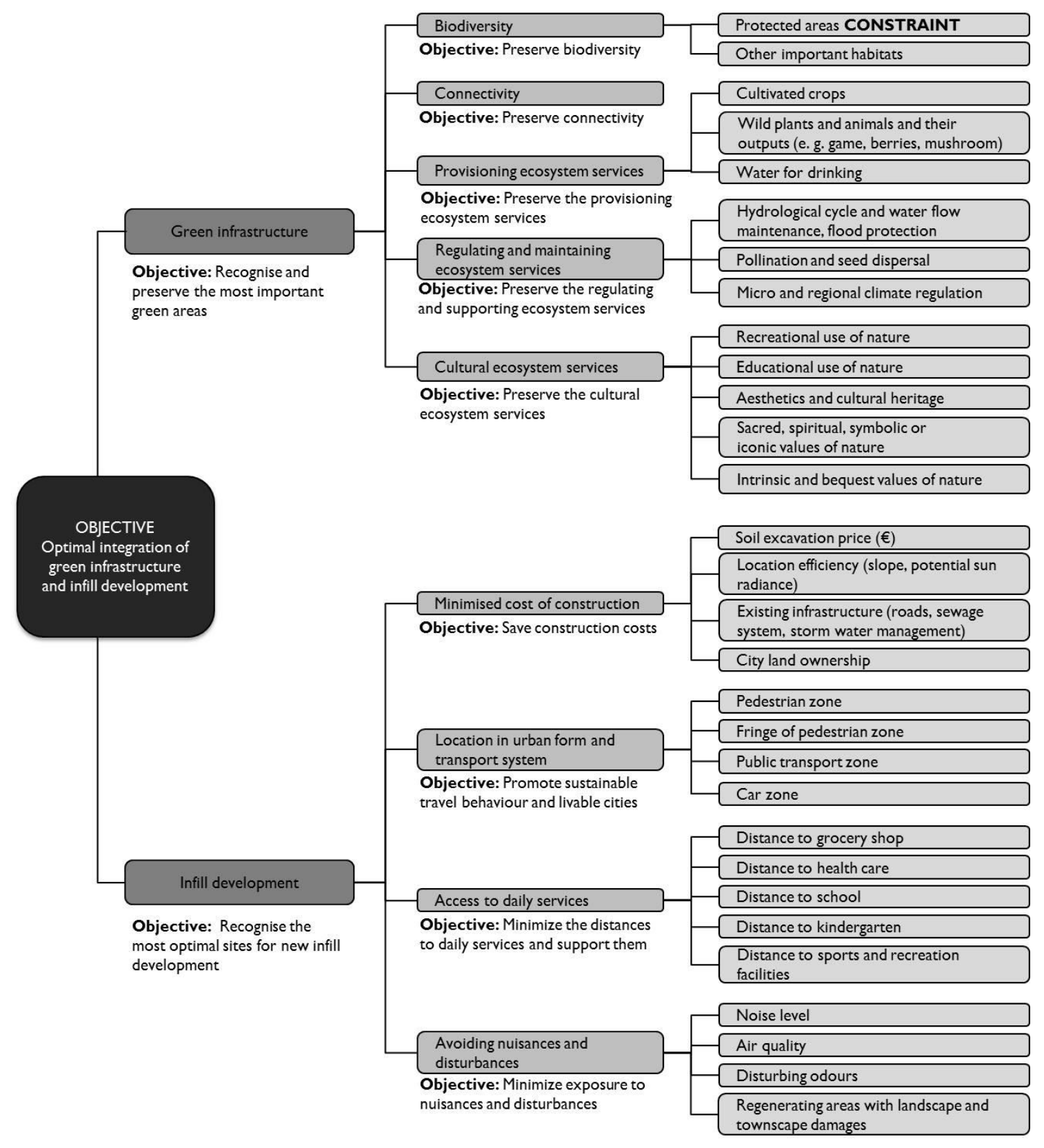

Fig. 2. Structure of the value tree including the objectives and the criteria for the integration of green infrastructure (GI) and infill development. 


\subsection{Data analysis}

Available spatial data was reviewed to find the most suitable data to represent the criteria. This phase was researcher-driven. For example, to evaluate the biodiversity, we used the presence of conservation areas and other environmentally important nature areas, which included the Natura 2000 sites, nature reserves on public and private land, nature conservation program areas, new areas proposed for conservation by the City of Järvenpää, habitats of special importance according to the Forest Act, habitats of endangered species, and important bird areas. A comprehensive listing of the used spatial data is described in Appendix A. All the datasets were converted into raster layers with a spatial resolution of 20 metres.

The potential provision of 11 different ecosystem services (including provisioning, regulating and maintenance, and cultural ecosystem services according to the Common International Classification of Ecosystem Services, CICES v.4.3 ${ }^{1}$ ), earlier selected by the land-use planners of the city, were analysed using the GreenFrame method (Kopperoinen et al., 2014). Datasets on biodiversity were included in the GreenFrame analysis due to their significance for the provision potential of specific ecosystem services, mainly cultural ecosystem services in the case of the City of Järvenpää. However, the location of protected areas and other important natural areas that are established on state-owned lands by law or by government regulation or on privately-owned lands by the decision of Finland's environmental administration were also included in the analysis, since the practitioners wanted to keep it as an independent sub-criteria in the value tree. Due to the conservation status, the protected areas were set as a constraint by the practitioners, preventing construction in that location. Other potential constraints were also discussed such as land own, but this was left out as the city representatives pointed out the possibility to buy the private land if necessary. The structural connectivity of green infrastructure was assessed by applying a graph-theory-based method using MatrixGreen and Conefor 2.6 software to quantify the importance of each habitat in terms of habitat size and distance to other habitats to maintain overall

\footnotetext{
${ }^{1}$ https://cices.eul
} 
connectivity (Saura and Torné, 2009; Bodin and Zetterberg, 2010). Linear value functions were applied for connectivity values.

Accessibility to different kinds of services affects the daily travel behaviour of residents and thus the preconditions for sustainable urban form. We applied a one-kilometre range and a linear value function to describe accessibility to daily services (i.e. health care facilities, schools and kindergartens), since for example, within one kilometre from the school, children still primarily walk to school in Finland (Strandell, 2017). For grocery shops, we used a lower range of 500 metres, since walking to grocery shops decreases considerably at distances above 500 metres (Strandell, 2017). For the recreation, we used a threshold of 300 metres as longer distances have been reported as influencing people's recreational behaviour by decreasing the usage of recreation areas and facilities (Coles and Bussey, 2000; Niemelä et al., 2010; Schipperijn et al., 2010; Söderman et al., 2012). As a result, the highest values were given to the pixels closer to the facility from where the values decrease according to Euclidean distance.

The medians calculated from the individual weights were integrated into the corresponding spatial datasets to assess the GI values and potential infill development sites on a map. Scores were cumulative, multiplied from the upper criteria level to the sub-criteria. We applied standardisation functions to make the criteria comparable by translating the original scores to a common scale ranging from 0 to 1 . The most suitable infill development sites and areas with highest GI values were the pixels with the highest values.

\subsection{Feedback workshop}

After producing the output maps according to the practitioner weightings, the results were sent to the participants and a feedback workshop was organised. The participants were the same as in the weighting workshop, with an additional GIS expert from the city attending as well. First the results were presented, and then feedback on the results and on the method was collected according to predefined questions (Table 2) as a round-table discussion. The questions dealt with i) logic and visualisations of the results, ii) 
personal opinion of the SMCDA process, iii) benefits of SMCDA for urban planning and decisionmaking, and iv) potential and challenges in applying SMCDA in the future. 
Table 2. The questions discussed in the feedback workshop as a round-table discussion.

\begin{tabular}{|c|c|}
\hline Theme & Question \\
\hline $\begin{array}{r}\text { Logic and } \\
\text { visualisation of the } \\
\text { results }\end{array}$ & $\begin{array}{l}\text { i. Do the resulting maps look logical and coherent } \\
\text { with your insight into the green infrastructure / } \\
\text { infill development related values of the city? } \\
\text { a. Is the fourfold table and a map with four } \\
\text { spatial classes a good way to present the } \\
\text { results? } \\
\text { b. What possible controversies do the } \\
\text { outcome maps have in your opinion? }\end{array}$ \\
\hline $\begin{array}{r}\text { Personal opinion } \\
\text { of the process }\end{array}$ & $\begin{array}{l}\text { ii. What is your personal opinion of the overall } \\
\text { SMCDA experience? }\end{array}$ \\
\hline Benefits & $\begin{array}{l}\text { iii. What kind of benefits could the method bring for } \\
\text { urban planning and decision-making? }\end{array}$ \\
\hline $\begin{array}{r}\text { Potential and } \\
\text { challenges in the } \\
\text { future }\end{array}$ & $\begin{array}{l}\text { iv. How can the City of Järvenpää apply the method } \\
\text { in the future, and what kind of challenges do you } \\
\text { anticipate concerning that? }\end{array}$ \\
\hline
\end{tabular}




\section{Results}

\subsection{Results of SMCDA}

The median weights with the standard deviations in parentheses for different criteria given by the practitioners are presented in the Table 3. Both the GI and infill development criteria were almost equally important for the practitioners in the highest hierarchy level with deviation of 4 and 7 units respectively. In the subcriteria II level, the weightings differed most in cultivated crops and land ownership criteria with deviation 25 and 24. Drinking water was seen equally important among the practitioners, having the maximum weight from every practitioner.

The results were presented as maps for green infrastructure values and urban form criteria both separately and combined using the values from the total weight column. The combination of both themes was a fourfold table and a map of four different spatial classifications. By cross tabulating the values, four classes were distinguished in relation to individual pixel's GI values and suitability for infill development: i) low GI values, low infill development potential ii) high GI values, low infill potential iii) high GI values, high infill development potential, and iv) low GI values and high infill development potential. The first class represented areas with no competing interests, and the second stood for areas preferably to be preserved as green areas. The third class described areas with possible conflicts between GI and infill development, since both values were high. The essential fourth class signified the areas with the most potential infill sites, with high construction potential but low GI values. The class boundaries were defined as median values (Fig. 3).

A spatial visualisation of the results is presented in Fig. 4. According to the results, the values of green infrastructure are highest in the areas located outside the city centre, particularly the large forested areas that serve as the main recreational areas of the city. In contrast, the most suitable construction sites are located closer to the already densely-populated area surrounding the city centre. 
Table 3. The medians and standard deviations in parentheses calculated from the practitioners' individual weights (max. 100) and the cumulative weights for different criteria.

\begin{tabular}{|c|c|c|c|c|c|c|}
\hline Criteria & Weights & I Subcriteria & Weights & II Subcriteria & Weights & $\begin{array}{c}\text { Total } \\
\text { weight }\end{array}$ \\
\hline \multirow{14}{*}{ 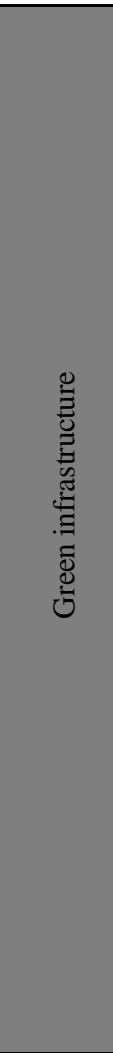 } & \multirow{14}{*}{$\begin{array}{l}100 \\
(4)\end{array}$} & \multirow{2}{*}{ Biodiversity } & \multirow{2}{*}{$\begin{array}{r}100 \\
(15)\end{array}$} & Conservation areas & $\begin{array}{r}100 \\
(15)\end{array}$ & 1.00 \\
\hline & & & & Other important natural areas & $\begin{array}{l}90 \\
(8)\end{array}$ & 0.90 \\
\hline & & Connectivity & $\begin{array}{c}90 \\
(14)\end{array}$ & $*$ & $*$ & 0.90 \\
\hline & & \multirow{3}{*}{$\begin{array}{l}\text { Provisioning } \\
\text { ecosystem services }\end{array}$} & \multirow{3}{*}{$\begin{array}{c}90 \\
(13)\end{array}$} & Cultivated crops & $\begin{array}{c}60 \\
(25) \\
\end{array}$ & 0.54 \\
\hline & & & & Wild plants and animals and their outputs & $\begin{array}{l}80 \\
(9)\end{array}$ & 0.72 \\
\hline & & & & Drinking water & $\begin{array}{l}100 \\
(0)\end{array}$ & 0.90 \\
\hline & & \multirow{3}{*}{$\begin{array}{l}\text { Regulative and } \\
\text { supporting ecosystem } \\
\text { services }\end{array}$} & \multirow{3}{*}{$\begin{array}{l}80 \\
(8)\end{array}$} & $\begin{array}{l}\text { Hydrological cycle and water flow } \\
\text { maintenance, flood protection }\end{array}$ & $\begin{array}{l}100 \\
(9)\end{array}$ & 0.80 \\
\hline & & & & Pollination and seed dispersal & $\begin{array}{c}80 \\
(13) \\
\end{array}$ & 0.64 \\
\hline & & & & Micro and regional climate regulation & $\begin{array}{c}90 \\
(19)\end{array}$ & 0.72 \\
\hline & & \multirow{5}{*}{$\begin{array}{l}\text { Cultural ecosystem } \\
\text { services }\end{array}$} & \multirow{5}{*}{$\begin{array}{c}90 \\
(10)\end{array}$} & Recreational use of nature & $\begin{array}{l}100 \\
(5)\end{array}$ & 0.90 \\
\hline & & & & Educational use of nature & $\begin{array}{c}80 \\
(10) \\
\end{array}$ & 0.72 \\
\hline & & & & Aesthetics and cultural heritage & $\begin{array}{c}80 \\
(13) \\
\end{array}$ & 0.72 \\
\hline & & & & $\begin{array}{l}\text { Sacred, spiritual, symbolic or iconic values of } \\
\text { nature }\end{array}$ & $\begin{array}{c}60 \\
(12) \\
\end{array}$ & 0.54 \\
\hline & & & & Intrinsic and bequest values of nature & $\begin{array}{l}100 \\
(8)\end{array}$ & 0.90 \\
\hline \multirow{17}{*}{ 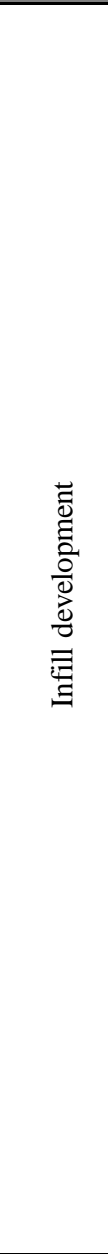 } & \multirow{17}{*}{$\begin{array}{l}100 \\
(7)\end{array}$} & \multirow{4}{*}{$\begin{array}{l}\text { Suitability of the } \\
\text { location for } \\
\text { construction }\end{array}$} & \multirow{4}{*}{$\begin{array}{c}80 \\
(13)\end{array}$} & Soil excavation price $(€)$ & $\begin{array}{c}90 \\
(13)\end{array}$ & 0.72 \\
\hline & & & & $\begin{array}{l}\text { Existing infrastructure (roads, sewage system, } \\
\text { storm water management) }\end{array}$ & $\begin{array}{l}90 \\
(8)\end{array}$ & 0.72 \\
\hline & & & & Land ownership & $\begin{array}{c}70 \\
(24) \\
\end{array}$ & 0.56 \\
\hline & & & & $\begin{array}{l}\begin{array}{l}\text { Geographical energy efficiency (minimum } \\
\text { slope, potential sun radiance) }\end{array} \\
\end{array}$ & $\begin{array}{c}80 \\
(16) \\
\end{array}$ & 0.64 \\
\hline & & \multirow{4}{*}{$\begin{array}{l}\text { Location in urban form } \\
\text { and transport system }\end{array}$} & \multirow{4}{*}{$\begin{array}{l}90 \\
(8)\end{array}$} & Pedestrian zone & $\begin{array}{l}100 \\
(10) \\
\end{array}$ & 0.90 \\
\hline & & & & Fringe of pedestrian zone & $\begin{array}{c}90 \\
(11)\end{array}$ & 0.81 \\
\hline & & & & Public transport zone & $\begin{array}{l}80 \\
(6) \\
\end{array}$ & 0.72 \\
\hline & & & & Car zone & $\begin{array}{c}70 \\
(15) \\
\end{array}$ & 0.63 \\
\hline & & \multirow{5}{*}{$\begin{array}{l}\text { Access to daily } \\
\text { services }\end{array}$} & \multirow{5}{*}{$\begin{array}{c}90 \\
(10)\end{array}$} & Distance to grocery shop & $\begin{array}{c}90 \\
(15) \\
\end{array}$ & 0.81 \\
\hline & & & & Distance to school & $\begin{array}{c}80 \\
(19) \\
\end{array}$ & 0.72 \\
\hline & & & & Distance to kindergarten & $\begin{array}{c}90 \\
(18)\end{array}$ & 0.81 \\
\hline & & & & Distance to sports and recreation facilities & $\begin{array}{c}70 \\
(13) \\
\end{array}$ & 0.63 \\
\hline & & & & Distance to health care & $\begin{array}{c}80 \\
(15) \\
\end{array}$ & 0.72 \\
\hline & & \multirow{4}{*}{$\begin{array}{l}\text { Minimised exposure to } \\
\text { nuisances and } \\
\text { disturbances }\end{array}$} & \multirow{4}{*}{$\begin{array}{l}70 \\
(12)\end{array}$} & Noise level & $\begin{array}{c}80 \\
(12) \\
\end{array}$ & 0.56 \\
\hline & & & & Air quality & $\begin{array}{l}100 \\
(14) \\
\end{array}$ & 0.70 \\
\hline & & & & Disturbing odours & $\begin{array}{c}60 \\
(18) \\
\end{array}$ & 0.42 \\
\hline & & & & $\begin{array}{l}\text { Regenerating areas with landscape and } \\
\text { townscape damages }\end{array}$ & $\begin{array}{c}85 \\
(16)\end{array}$ & 0.60 \\
\hline
\end{tabular}




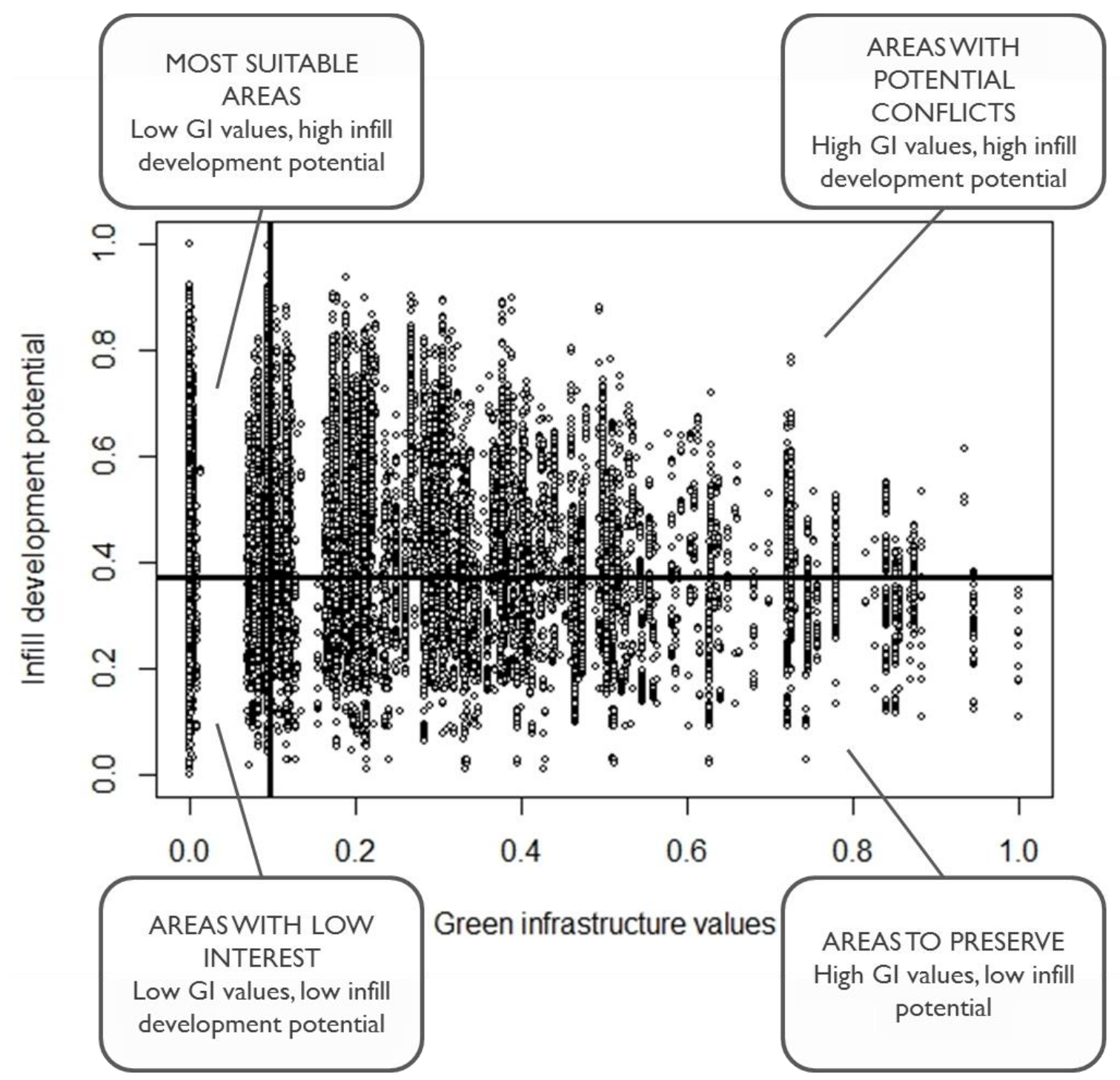

Fig. 3. Visualisation of the results: a fourfold table with an interpretation of each class. Classes are formed according to the median based on the individual pixel values. 


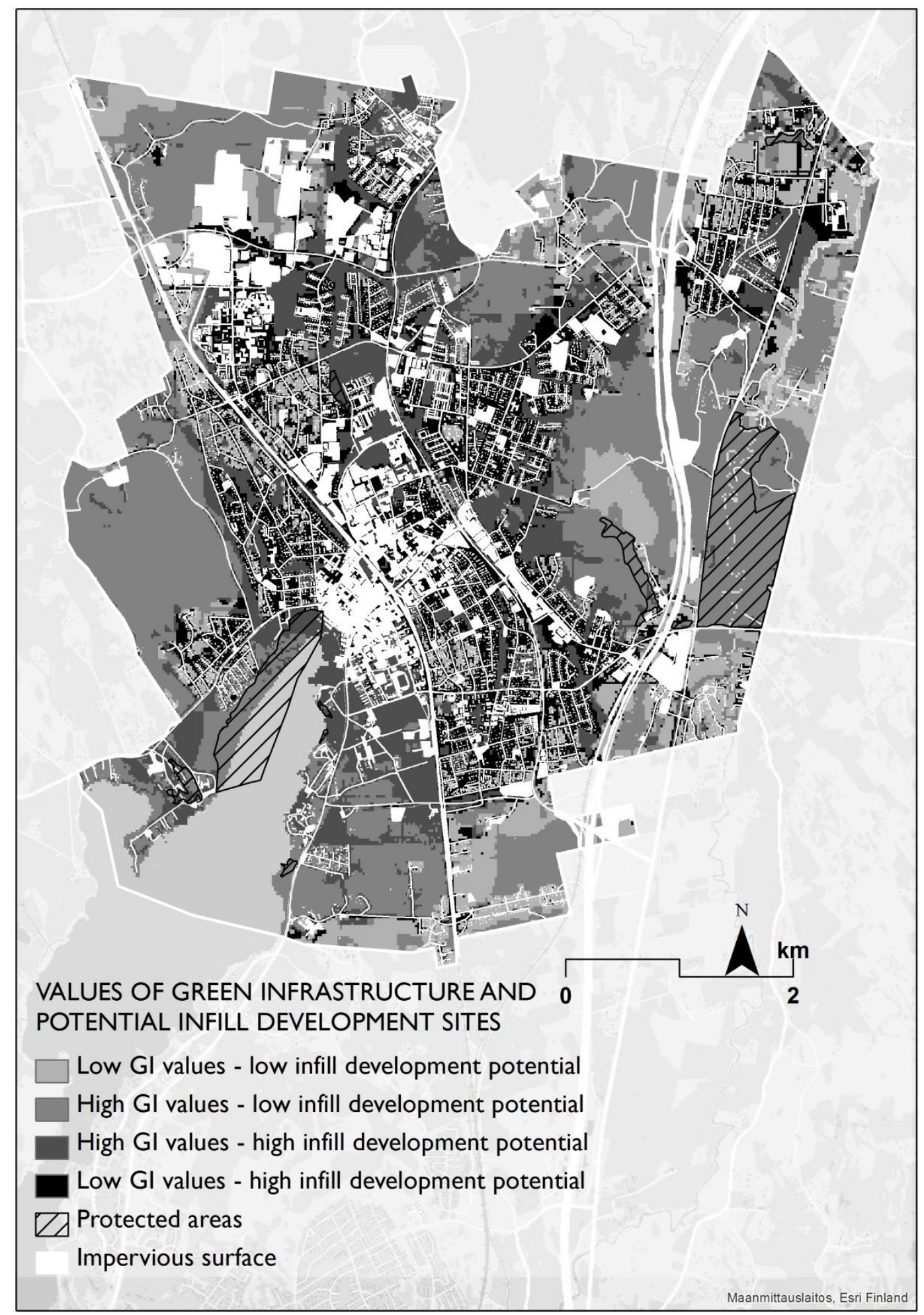

Fig. 4. Visualisation of the results: a classified map with an interpretation of each class. Classes are formed according to the median based on the individual pixel values. 


\subsection{Results of the feedback workshop}

The practitioners saw the results as logical and a good representation of their city's values from the perspective of green infrastructure. However, based on their local knowledge, they pointed out that the accessibility to the school and kindergarten network — which they valued rather high in the weightingsseemed to be biased toward the overall suitability by highlighting residential construction in locations too far from the city centre. This was partially because the distance for the services was calculated with an accessibility range of one kilometre, which covers a large part of the city. It was also discussed whether the acceptable distance to the health care should be more than one kilometre. Some participants pointed out that the future of the social and health care system related to a digitalisation of services is uncertain, and that will probably change the need for physical treatment and thus influence the urban form. It was also discussed that the importance of the distance to the nearest school or kindergarten is rather irrelevant since the families do not often get their children into the nearest service.

The map with four different classes representing different potential for infill development was considered an illustrative approach for presenting the results. However, for improving the interpretation of the best infill development sites, more cross-tabulated spatial classes would be needed. The practitioners wanted to see more variety among the most potential sites. After seeing their cross-tabulated weightings on a map, the practitioners started to think of additional criteria that could have been included in the analysis and wondered how these would have affected the results. The discussed additional criteria covered traditional planning themes such as land-use efficiency and distance to additional services such as libraries, concert halls, etc.

Concerning the overall experience of the method, the feedback was mainly positive: The participants understood the overall concept and its objectives. However, they found difficulties in scaling the weights for different criteria against each other. It was difficult for them to see what kind of impact an individual weight has on the results. Some practitioners would have been interested in seeing the impact of different weights on the final map on-the-fly. 
The practitioners emphasised the importance of reserving enough time beforehand to get familiar with the method and with the required background information concerning the planning problem. In addition, enough time for adjusting the criteria in situ during the workshop was considered very important as well.

The practitioners saw much potential in the method to improve infill development planning. The value tree was seen as useful to structure the factors that affect infill development, and it provided a visual way to understand the challenge of weighting different factors against each other. A major benefit mentioned was that the SMCDA method brought people from different sectors of the city to the same table to discuss the complex systems and different factors affecting infill development. The resulting maps were considered to be a useful way to communicate with the decision-makers. The possibility to compare environmental values with the infill potential was considered to be especially valuable, since the map provides knowledge about the areas with an environmentally high value that should be preserved.

The resulting maps and the value tree were seen as one valuable data source for the planning process, providing comprehensive knowledge of the different criteria affecting infill development. It does not (and does not have to) provide all the possible information. The practitioners pointed out that there are in fact, many other factors (such as land use politics, renewal of existing structures, and existing distribution of building types) that are important and need to be considered in the planning process. The iteration potential, with the possibility of adding more criteria and seeing their impact on the results, was highly appreciated.

Finally, the method was seen as a potential means to include experts' knowledge and perceptions in an equal manner for making more informed decisions. The practitioners were enthusiastic about applying the method widely (with local residents' associations and other stakeholders) for the new master plan, but they were concerned about resources, since the method requires researcher-facilitated workshops and advanced GIS knowled ge. 


\section{Discussion}

In this article, we have studied the benefits and challenges in applying SMCDA to the integration of green infrastructure and infill development in land use planning in the Finnish City of Järvenpää. Infill development planning is a more complex process than developing new areas outside the city, since it is typically focused on areas with existing residents, buildings, infrastructure, and fairly established values related to certain places. That is why SMCDA is a potential tool for integrating the often conflicting themes: natural values and ecosystem services provided by blue-green infrastructure, and development of areas. Despite the growing use of planning support systems (Malczewski, 2006), many case studies applying SMCDA do not focus on the role of stakeholders or on feedback from them. By providing a detailed description of the practitioners' feedback, highlighting their impressions and experiences related to method development, we analysed the potential of SMCDA for wider use in integrating conflicting objectives related to infill development.

According to the results, the practitioners struggled the most with the criteria weightings and their impact on the results. The weights of the selected criteria are often the greatest contributor to controversy and uncertainty of the results (Chen et al., 2010). An application of MCDA in systems engineering (Shukla and Auriol, 2013) suggests that the most critical challenge concerning criteria weighting is the cognitive load on the decision-maker. The practitioners in Järvenpää also emphasised that the low cognitive load of the method is very important. This directly relates to the usability of the method in general: If the decision-makers find it difficult to weight the criteria, the technique has fewer chances to be used in the process (Shukla and Auriol, 2013). However, Montibeller and von Winterfeldt (2015) have proved that weight elicitation method has a significant impact on the resulting weights. This causes SMCDA procedure a dilemma between simplicity and use of a complex mathematical weight elicitation technique. In this study, a modified swing technique was used in order to reduce the cognitive load on practitioners, and it might have an effect on the weightings compared to using another technique. 
The SMCDA map presenting infill development potential in the City of Järvenpää was seen slightly biased by the practitioners. In this study, the value tree comprised of a large number of subcriteria. Because individual criteria typically receive very small weights and the impact of an individual criterion on the outcome can be marginal, large number of criteria could potentially bias the results. Some important criteria may even be overridden by the number of less important criteria (Marttunen et al., 2018). However, the criteria selection also explains why the suitable infill development sites seemed to be located too far from the centre according to the practitioners. In fact, not many of the criteria selected to describe suitable construction sites represent functions that specifically gravitate towards the city centre (for example soil type, proximity of sport and recreation facilities, schools and kindergartens).

In SMCDA, the weightings have a great impact on the resulting maps. This is why on-the-fly tools for sensitivity analyses, developed (for example) by Chen et al. (2010), for verifying the impacts of the weights on a map were considered useful by the practitioners in Järvenpää. As in all participatory GIS techniques, there is a potential risk of politicisation of the weightings. The weights could be intentionally adjusted so that certain areas rise or drop to a certain spatial class accordingly. These risks should be particularly concerned dealing with sensitive themes such as infill development. Similar issues can also be detected when selecting constraints. Land ownership was discussed to be a potential constraint, but only the protected areas were excluded from the potential construction sites. The City of Järvenpää is under a high pressure for building houses for new residents. This might restrain the practitioners from selecting other constraints than those based on the law, giving more options to infill development planning. However, land ownership was the criteria with second highest deviation in weights showing that there are different opinions prevailing between different city sectors. Although using median weightings based on several stakeholder weightings would diminish the politicking of the overall results, there is a risk of politicking that should be taken into account when using on-the fly techniques in stakeholder weightings. On the other hand, land-use decisions are based on conscious or unconscious weighting between different issues anyways; the benefit of the SMCDA is that the weightings become transparent and allow more open discussion on what is the importance of different factors and why. 
The suitability maps that were produced were considered as good visualisations for the practitioners to communicate with the decision-makers about potential infill development sites. However, it is important that all users of the maps should be aware of the restrictions of the results. This analysis concerned residential infill development site selection, and therefore some of the weak locations for residential development might still be well-suited for industrial development, for instance the noisy areas located near motorways. Thus, it should be highlighted that the maps resulting from SMCDA are not objective but are based on subjective weightings made by participants involved in the process. This highlights the importance of transparency and the comprehensive explanation of each step of the method to understand the results on a map. In this study, we used a few maps to present the results of a complex process where the number of classes in the output map has a great impact on the interpretation of the results. This relates to the widely known problems of misleading with maps, which should be acknowledged to avoid an oversimplifying interpretation of the results (Monmonier, 1996).

One of the limitations of this study is that the SMCDA method was tested only with practitioners of the city acting as stakeholders. In the workshops, the practitioners seemed to have much wider knowledge of good infill development site criteria than the criteria concerning green infrastructure and ecosystem services. It was described by the fact that they leant much more on the researcher-drafted criteria when discussing GI values than when discussing urban form. In addition, the feedback was given more about the infill development theme. Although both the interest as well as knowledge on ecosystem services has increased for example among land use planners since Niemelä et al. (2010), who reported that ecosystem services were still unknown by a large group of experts and non-experts, the application of the concept is still often based on collaboration with researchers or other ecosystem service experts (Dick et al., 2018). It means that when applying the SMCDA on a larger scale, it would be important to ensure equal expertise covering different themes in the workshops. Then again, the SMCDA provides a tool for practitioners to expand their knowledge on certain themes in joint discussions with experts representing different fields of expertise, for instance ecosystem services. 
Regarding the resulting maps of the SMCDA application in the City of Järvenpää, a clear division could be seen between low values of GI in the already densely built-up areas and high values of GI in the fringe of the city. However, from the ecosystem services point of view, green spaces have important functions inside the city. They improve the well-being of citizens and save energy by providing water retaining areas, lowering local temperatures, and providing shade by vegetation. Ecosystem services cannot be outsourced from the densely built-up area even if they get lower values in the city centre than in the urban fringe. This raised a question, both among the authors and practitioners, whether the method should be applied solely to the already dense areas. Another option is to increase the number of spatial classes to have more variation in the resulting suitability maps.

The practitioners did not see the GIS datasets on the map when weighting the criteria. This is one possible source of the challenge in acknowledging the differences between the individual weightings and the outcome on the map. Therefore, the available GIS data could be explored simultaneously with defining the criteria together with the participants. This way, the participants would be familiar with the accuracy and resolution of the source data that (as in any participatory GIS analyses) has a direct impact on the quality of the outcome maps (Nyerges et al., 2011). However, not seeing the GIS datasets on the map is also a benefit of SMCDA because it may result in more objective weightings.

This study created a need for further studies applying SMCDA to the integration of GI and infill development in cities. First, the effects of applying on-the-fly weighting techniques on the usability of SMCDA should be further studied from the stakeholders' perspective. The more explicit and meaningful the stakeholders consider the method, the more widely the method will probably be used. Secondly, further research is needed on how the SMCDA process has an actual effect on planning practices and the ultimate land use plan: Does the use of the method result in more informed decisions and more sustainable land-use plans? Could this be a way to apply the concept of ecosystem services more into land use planning, which is still rarely manifested as a mechanism for actual planning practices and land-use decisions (BenDor et al., 2017)? Regardless of the limitations, SMCDA brought together experts from different sectors of the city to discuss the complex planning problem, which already supports the 24 
integration of conflicting land uses in the city. However, development of the criteria weighting process and improving the stakeholders' understanding of their impacts on the results would improve the usability of SMCDA in terms of the integrated planning of infill development and green infrastructure.

\section{Conclusions}

SMCDA is a tool with a high potential to support the complex integration of GI values and infill development. The most important benefits according to the practitioners were the ability to structure the complex criteria together in an organised manner. The most difficult part for them was to understand the impact of individual weightings on the results. The simplified content of the resulting maps created a challenge for communication with the decision-makers or other groups that are not aware of the underlining process of the results. The SMCDA process is most useful when conducted in close collaboration with local practitioners and stakeholders with a wide range of expertise. The collaboration during the process should be continuous and communication clear with sufficient knowledge of the method's limitations. Key further developments of SMCDA in integrating GI and infill development in cities include the impacts on the on-the-fly testing of GIS data during the weightings and the actual impact of the process on planning practices.

\section{Acknowledgements}

Writing of this article has been funded by Strategic Research Council (SRC) at Academy of Finland for the project "Beyond MALPE-coordination: Integrative Envisioning (BeMInE, project number 303556). The research was funded by the Finnish Ministry of the Environment, and partly by the City of Järvenpää and Finnish Transport Agency. The authors would also like to thank the practitioners of the City of Järvenpää for a fruitful cooperation during the process, and for the wide variety of high quality GIS data to conduct the analyses. 


\section{References}

Angiella, S, M Bottero, S Corrente, V Ferretti, S Greco and IM Lami (2016). Non Additive Robust Ordinal Regression for urban and territorial planning: an application for siting an urban waste landfill. Annals of Operations Research, 245, 427-456.

Bagli, S, D Geneletti and F Orsi (2011). Routeing of power lines through least-cost path analysis and multicriteria evaluation to minimise environmental impacts. Environmental Impact Assessment Review, 31, 234-239.

Banville, C, M Landry, J-M Martel and C Boulaire (1998). A stakeholder approach to MCDA. Systems Research and Behavioral Science, 15, 15-32.

Bendor, TK., D Spurlock, SC Woodruff and L Olander (2017). A research agenda for ecosystem services in American environmental and land use planning. Cities, 60, 260-271.

Benedict, MA and ET McMahon (2012). Green infrastructure: Linking landscapes and communities, Washington, DC: Island Press.

Bodin, Ö and A Zetterberg (2010). MatrixGreen User's Manual: Landscape Ecological Network Analysis Tool. Stockholm.

Bottero, M, E Comino, M Duriavig, V Ferretti, and S Pomarico (2013). The application of a Multicriteria Spatial Decision Support System (MCSDSS) for the assessment of biodiversity conservation in the Province of Varese (Italy). Land Use Policy, 30, 730-738.

Brunner, J and P Cozens (2013). 'Where Have All the Trees Gone?' Urban Consolidation and the Demise of Urban Vegetation: A Case Study from Western Australia. Planning Practice \& Research, 28, 231-255.

Chen, Y, J YU and S Khan (2010). Spatial sensitivity analysis of multi-criteria weights in GIS-based land suitability evaluation. Environmental Modelling \& Software, 25, 1582-1591.

Coles, RW and SC Bussey (2000). Urban forest landscapes in the UK - progressing the social agenda. Landscape and Urban Planning, 52, 181-188.

Dallimer, M, Z Tang, PR Bibby, P Brindley, KJ Gaston, and ZG Davies (2011). Temporal changes in greenspace in a highly urbanized region. Biology Letters, 7(5), 763-766.

Delle Site, P and F Filippi (2009). Weighting methods in multi-attribute assessment of transport projects. European Transport Research Review, 1, 199-206.

Delmelle, E, Y Zhou and JC Thill (2014). Densification without Growth Management? Evidence from Local Land Development and Housing Trends in Charlotte, North Carolina, USA. Sustainability, 6, 3975-3990.

Dick, J, F Turkelboom, H Woods, I Iniesta-Arandia, E Primmer, E., SR Saarela., P Bezák, P Mederly, M Leone, W Verheyden, E Kelemen, J Hauck, C Andrews, P Antunes, R Aszalós, F Baró, DN Barton, P Berry, R Bugter, L Carvalho, B Czúcz, R Dunford, G Garcia Blanco, N Geamănă, R Giucă, B Grizzetti, Z Izakovičová, M Kertész, L Kopperoinen, J Langemeyer, D Montenegro Lapola, C Liquete, S Luque, G Martínez Pastur, B Martin-Lopez, R Mukhopadhyay, J Niemelä, D Odee, PL Peri, P Pinho, GB Patrício-Roberto, E Preda, J Priess, C Röckmann, R Santos, D Silaghi, R Smith, A Vădineanu, JT van der Wal, I Arany, O Badea, G Bela, E Boros, M Bucur, S Blumentrath, M Calvache, E Carmen, P Clemente, J Fernandes, D Ferraz, C Fongar, M García-Llorente, E GómezBaggethun, V Gundersen, O Haavardsholm, Á Kalóczkai, T Khalalwe, G Kiss, B Köhler, O Lazányi, E LelleiKovács, R Lichungu, H Lindhjem, C Magare, J Mustajoki, C Ndege, M Nowell, S Nuss Girona, J Ochieng, A Often, I Palomo, G Pataki, R Reinvang, G Rusch, H Saarikoski, A Smith, E Soy Massoni, E Stange, N Vågnes Traaholt, Á Vári, P Verweij, S Vikström, V Yli-Pelkonen and G Zulian (2018). Stakeholders' perspectives on the 
operationalisation of the ecosystem service concept: Results from 27 case studies. Ecosystem Services, 29, 552565.

Ferretti, V (2016). From stakeholders analysis to cognitive mapping and Multi-Attribute Value Theory: An integrated approach for policy support. European Journal of Operational Research, 253(2), 524-541.

Ferretti, V and E Comino (2015). An integrated framework to assess complex cultural and natural heritage systems with Multi-Attribute Value Theory. Journal of Cultural Heritage, 16(5), 688-697.

Ferretti, V and S Pomarico (2013). Ecological land suitability analysis through spatial indicators: An application of the Analytic Network Process technique and Ordered Weighted Average approach. Ecological Indicators, 34, 507519.

Fuller, RA and KJ Gaston (2009). The scaling of green space coverage in European cities. Biology Letters, 5(3), 352-355.

Geneletti, D (2005). Multicriteria analysis to compare the impact of alternative road corridors: a case study in northern Italy. Impact Assessment and Project Appraisal, 23(2), 135-146.

Geneletti, D (2010). Combining stakeholder analysis and spatial multicriteria evaluation to select and rank inert landfill sites. Waste Management, 30(2), 328-337.

Geneletti, D and I van Duren (2008). Protected area zoning for conservation and use: A combination of spatial multicriteria and multiobjective evaluation. Landscape and Urban Planning, 85(2), 97-110.

Haaland, C and CK van den Bosch (2015). Challenges and strategies for urban green-space planning in cities undergoing densification: A review. Urban Forestry \& Urban Greening, 14(4), 760-771.

Huang, IB, J Keisler and I Linkov (2011). Multi-criteria decision analysis in environmental sciences: Ten years of applications and trends. Science of The Total Environment, 409(19), 3578-3594.

Ianni, E and D Geneletti (2010). Applying the Ecosystem Approach to Select Priority Areas for Forest Landscape Restoration in the Yungas, Northwestern Argentina. Environmental Management, 46(5), 748-760.

Janssen, R, H Goosen, ML Verhoeven, JTA Verhoeven, AQA Omtzigt and E Maltby (2005). Decision support for integrated wetland management. Environmental Modelling \& Software, 20(2), 215-229.

Kabisch, N and D Haase (2013). Green spaces of European cities revisited for 1990-2006. Landscape and Urban Planning, 110 (Supplement C), 113-122.

Karjalainen, TP, M Marttunen, S Sarkki and AM Rytkönen (2013). Integrating ecosystem services into environmental impact assessment: An analytic-deliberative approach. Environmental Impact Assessment Review, $40,54-64$.

Keeney, RL and RS Gregory (2005). Selecting Attributes to Measure the Achievement of Objectives. Operations Research, 53(1), 1-11.

Kenworthy, J (2007). Urban Planning and Transport Paradigm Shifts for Cities of the Post-Petroleum Age. Journal of Urban Technology, 14(2), 47-70.

Kiker, GA, TS Bridges, A Varghese, PT Seager and I Linkov (2005). Application of multicriteria decision analysis in environmental decision making. Integrated Environmental Assessment and Management, 1(2), 95-108.

Kimball, M, M Chester, C Gino and J Reyna (2013). Assessing the Potential for Reducing Life-Cycle Environmental Impacts through Transit-Oriented Development Infill along Existing Light Rail in Phoenix. Journal of Planning Education and Research, 33(4), 395-410. 
Kopperoinen, L, P Itkonen and J Niemelä (2014). Using expert knowledge in combining green infrastructure and ecosystem services in land use planning: an insight into a new place-based methodology. Landscape Ecology, 29(8), 1361-1375.

Kopperoinen, L, M Tiitu, A Viinikka and P Itkonen (2016). The values and benefits of the green infrastructure in the City of Järvenpää (in Finnish). Helsinki: Finnish Environment Institute and City of Järvenpää.

Kremer, P, ZA. Hamstead and T McPhearson (2016). The value of urban ecosystem services in New York City: A spatially explicit multicriteria analysis of landscape scale valuation scenarios. Environmental Science \& Policy, 62, $57-68$.

Mahmoud, MR and LA Garcia (2000). Comparison of different multicriteria evaluation methods for the Red Bluff diversion dam. Environmental Modelling \& Software, 15(5), 471-478.

Malczewski, J (2006). GIS-based multicriteria decision analysis: a survey of the literature. International Journal of Geographical Information Science 20(7), 703-726.

Marttunen, M, V Belton and J Lienert (2018). Are objectives hierarchy related biases observed in practice? A metaanalysis of environmental and energy applications of Multi-Criteria Decision Analysis. European Journal of Operational Research, 265(1), 178-194.

Marttunen, M, J Mustajoki, M Dufva and TP Karjalainen (2015). How to design and realize participation of stakeholders in MCDA processes? A framework for selecting an appropriate approach. EURO Journal on Decision Processes, 3(1), 187-214.

Millenium Ecosystem Assessment (2005). Ecosystems and human well-being: biodiversity synthesis, Washington DC: World Resources Institute.

Monmonier, M. (1996). How to Lie with Maps. Chicago and London: The University of Chicago Press.

Montibeller, G and D von Winterfeldt (2015). Cognitive and Motivational Biases in Decision and Risk Analysis. Risk Analysis, 35(7), 1230-1251.

Niemelä, J, SR Saarela, T Söderman, L Kopperoinen, V Yli-Pelkonen, S Väre and J Kotze (2010). Using the ecosystem services approach for better planning and conservation of urban green spaces: A Finland case study. Biodiversity and Conservation, 19 (11), 3225-3243.

Nyerges, T, H Couclelis and R McMaster (eds.) (2011). The SAGE handbook of GIS and society. London: SAGE Publications Ltd.

Official Statistics of Finland (2018). Population projection [e-publication]. Helsinki: Statistics Finland

Orsi, F and D Geneletti (2010). Identifying priority areas for Forest Landscape Restoration in Chiapas (Mexico): An operational approach combining ecological and socioeconomic criteria. Landscape and Urban Planning, 94(1), 20-30.

Pharoah, T. (1996). Reducing the need to travel: A new planning objective in the UK?. Land Use Policy, 13(1), 2336.

Sarzynski, A, G Galster and L Stack (2014). Evolving United States metropolitan land use patterns. Urban Geography, 35(1), 25-47.

Saura, S and J Torné (2009). Conefor Sensinode 2.2: A software package for quantifying the importance of habitat patches for landscape connectivity. Environmental Modelling \& Software, 24, 135-139.

Schipperijn, J, O Ekholm, UK. Stigsdotter, M Toftager, P Bentsen, F Kamper-Jørgensen and TB Randrup (2010). Factors influencing the use of green space: Results from a Danish national representative survey. Landscape and Urban Planning, 95(3), 130-137. 
Shukla, V and G Auriol (2013). Methodology for Determining Stakeholders' Criteria Weights in Systems Engineering. Complex Systems Design and Management Conference, Paris: France.

Strandell, A. (2017). Residents' barometer 2016 - Residents' Survey on Residential Environments in Finland (in Finnish). Reports of the Finnish Environment Institute, 19/2017. Helsinki: Finnish Environment Institute.

Söderman, T, L Kopperoinen, P Shemeikka and V Yli-Pelkonen (2012). Ecosystem services criteria for sustainable development in urban regions. Journal of Environmental Assessment Policy and Management, 14(02), 1250008. 


\begin{tabular}{|c|c|c|c|}
\hline \multirow{7}{*}{ Biodiversity } & \multirow{4}{*}{ Conservation areas } & Natura 2000 areas & SYKE \\
\hline & & Nature reserves on public and private land & SYKE \\
\hline & & Nature conservation program areas & SYKE \\
\hline & & $\begin{array}{l}\text { New areas proposed for conservation by the City of } \\
\text { Järvenpää }\end{array}$ & City of Järvenpää \\
\hline & \multirow{3}{*}{ Other important natural areas } & Habitats of special importance according to Forest Act & City of Järvenpää \\
\hline & & Habitats of endangered species & City of Järvenpää \\
\hline & & Important bird areas & City of Järvenpää \\
\hline Connectivity & & Structural connectivity analysis of green patches & SYKE \\
\hline \multirow{4}{*}{$\begin{array}{l}\text { Provisioning } \\
\text { ecosystem } \\
\text { services }\end{array}$} & Cultivated crops & $\begin{array}{l}\text { GreenFrame analysis on the provision potential of the } \\
\text { particular ES }\end{array}$ & City of Järvenpää and SYKE \\
\hline & \multirow{2}{*}{$\begin{array}{l}\text { Wild plants and animals and their } \\
\text { outputs }\end{array}$} & $\begin{array}{l}\text { GreenFrame analysis on the provision potential of the } \\
\text { particular ES }\end{array}$ & City of Järvenpää and SYKE \\
\hline & & $\begin{array}{l}\text { PPGIS data on the particular ES aggregated into green } \\
\text { patches }\end{array}$ & City of Järvenpää and SYKE \\
\hline & Water for drinking & $\begin{array}{l}\text { GreenFrame analysis on the provision potential of the } \\
\text { particular ES }\end{array}$ & City of Järvenpää and SYKE \\
\hline \multirow{4}{*}{$\begin{array}{l}\text { Regulative } \\
\text { and } \\
\text { supporting } \\
\text { ecosystem } \\
\text { services }\end{array}$} & $\begin{array}{l}\text { Hydrological cycle and water flow } \\
\text { maintenance, flood protection }\end{array}$ & $\begin{array}{l}\text { GreenFrame analysis on the provision potential of the } \\
\text { particular ES }\end{array}$ & City of Järvenpää and SYKE \\
\hline & Pollination and seed dispersal & $\begin{array}{l}\text { GreenFrame analysis on the provision potential of the } \\
\text { particular ES }\end{array}$ & City of Järvenpää and SYKE \\
\hline & \multirow{2}{*}{$\begin{array}{l}\text { Micro and regional climate } \\
\text { regulation }\end{array}$} & $\begin{array}{l}\text { GreenFrame analysis on the provision potential of the } \\
\text { particular ES }\end{array}$ & City of Järvenpää and SYKE \\
\hline & & $\begin{array}{l}\text { PPGIS data on the particular ES aggregated into green } \\
\text { patches }\end{array}$ & City of Järvenpää and SYKE \\
\hline \multirow{10}{*}{$\begin{array}{l}\text { Cultural } \\
\text { ecosystem } \\
\text { services }\end{array}$} & \multirow{2}{*}{ Recreational use of nature } & $\begin{array}{l}\text { GreenFrame analysis on the provision potential of the } \\
\text { particular ES }\end{array}$ & City of Järvenpää and SYKE \\
\hline & & $\begin{array}{l}\text { PPGIS data on the particular ES aggregated into green } \\
\text { patches }\end{array}$ & City of Järvenpää and SYKE \\
\hline & \multirow[t]{2}{*}{ Educational use of nature } & $\begin{array}{l}\text { GreenFrame analysis on the provision potential of the } \\
\text { particular ES }\end{array}$ & City of Järvenpää and SYKE \\
\hline & & Survey for schools and kindergartens, PPGISdata & City of Järvenpää and SYKE \\
\hline & \multirow{2}{*}{ Aesthetics and cultural heritage } & $\begin{array}{l}\text { GreenFrame analysis on the provision potential of the } \\
\text { particular ES }\end{array}$ & City of Järvenpää and SYKE \\
\hline & & $\begin{array}{l}\text { PPGIS data on the particular ES aggregated into green } \\
\text { patches }\end{array}$ & City of Järvenpää and SYKE \\
\hline & \multirow{2}{*}{$\begin{array}{l}\text { Sacred, spiritual, symbolic or } \\
\text { iconic values of nature }\end{array}$} & $\begin{array}{l}\text { GreenFrame analysis on the provision potential of the } \\
\text { particular ES }\end{array}$ & City of Järvenpää and SYKE \\
\hline & & $\begin{array}{l}\text { PPGIS data on the particular ES aggregated into green } \\
\text { patches }\end{array}$ & City of Järvenpää and SYKE \\
\hline & \multirow{2}{*}{$\begin{array}{l}\text { Intrinsic and bequest values of } \\
\text { nature }\end{array}$} & $\begin{array}{l}\text { GreenFrame analysis on the provision potential of the } \\
\text { particular ES }\end{array}$ & City of Järvenpää and SYKE \\
\hline & & $\begin{array}{l}\text { PPGIS data on the particular ES aggregated into green } \\
\text { patches }\end{array}$ & City of Järvenpää and SYKE \\
\hline \multirow{4}{*}{$\begin{array}{l}\text { Minimised } \\
\text { cost of } \\
\text { construction }\end{array}$} & Soil & Cost of excavation of the subsoil & SYKE \\
\hline & $\begin{array}{l}\text { Existing infrastructure (roads, } \\
\text { sewage system, storm water } \\
\text { management) }\end{array}$ & Buffer zone of the road network & Digiroad \\
\hline & \begin{tabular}{|l|} 
Land ownership of the city \\
\end{tabular} & GIS data on parcels owned by the city & City of Järvenpää \\
\hline & $\begin{array}{l}\text { Energy efficiency potential of the } \\
\text { area }\end{array}$ & $\begin{array}{l}\text { Southward slopes (135-225 degrees) with a gradient } \\
\text { less than } 1: 5\end{array}$ & SYKE \\
\hline \multirow{4}{*}{$\begin{array}{l}\text { Location in } \\
\text { urban form } \\
\text { and transport } \\
\text { system }\end{array}$} & Pedestrian zone & Travel-related urban zone: pedestrian zone & SYKE \\
\hline & Fringe of pedestrian zone & Travel-related urban zone: fringe of pedestrian zone & SYKE \\
\hline & Public transport zone & Travel-related urban zone: public transport zone & SYKE \\
\hline & Car zone & Travel-related urban zone: car zone & SYKE \\
\hline \multirow{5}{*}{$\begin{array}{l}\text { Access to } \\
\text { daily services }\end{array}$} & Distance to grocery shop & Euclidean distance (max. $500 \mathrm{~m})$ & $\begin{array}{l}\text { Nielsen retail register and } \\
\text { SYKE }\end{array}$ \\
\hline & Distance to school & Euclidean distance (max. $1000 \mathrm{~m})$ & Statistics Finland and SYKE \\
\hline & \begin{tabular}{|l|} 
Distance to kindergarten \\
\end{tabular} & Euclidean distance (max. $1000 \mathrm{~m})$ & City of Järvenpää and SYKE \\
\hline & \begin{tabular}{|l|} 
Distance to sports and recreation \\
facilities
\end{tabular} & Euclidean distance (max. 300 m) & \begin{tabular}{|l|} 
University of Jyväskylä and \\
SYKE
\end{tabular} \\
\hline & Distance to health care & Euclidean distance (max. $1000 \mathrm{~m})$ & City of Järvenpää \\
\hline \multirow{2}{*}{$\begin{array}{l}\text { Avoiding } \\
\text { nuisances }\end{array}$} & Low noise level & Noisy areas & SYKE \\
\hline & Good air quality & Buffer zone of busy roads $(20 \mathrm{~m})$ & SYKE \\
\hline
\end{tabular}




\begin{tabular}{|l|l|l|l|}
\hline $\begin{array}{l}\text { and } \\
\text { disturbances }\end{array}$ & No disturbing odours & $\begin{array}{l}\text { Surface waters of passable or poor ecological status } \\
(\max .300 \mathrm{~m})\end{array}$ & SYKE \\
\cline { 2 - 4 } & $\begin{array}{l}\text { Regenerating areas with landscape } \\
\text { and townscape damages }\end{array}$ & Areas of disturbing landscape & City of Järvenpää \\
\hline
\end{tabular}

